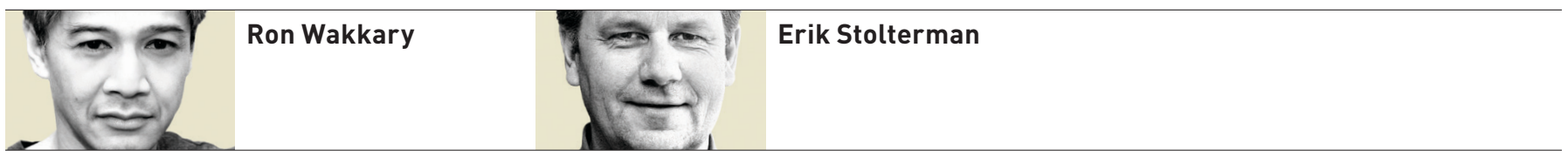

\title{
HCI 10 Years After
}

\begin{tabular}{|c|c|}
\hline $\begin{array}{l}2006, \\
\text { ced the } \\
\text { HCI. } \\
\text { arch } \\
\text { s, } \\
\text { his idea } \\
\text { own, and } \\
\text { In this } \\
\text { evisits her } \\
\text { on what } \\
\text { years. } \\
\text { at she sees } \\
\text { e field } \\
\text { ld move } \\
\text { oomments }\end{array}$ & $\begin{array}{l}\text { the Interacting with Public Policy } \\
\text { forum since } 2010 \text {. In his final article, } \\
\text { Lazar describes the progress that } \\
\text { has been made during the forum's } \\
\text { existence. Lazar writes, "For six } \\
\text { years, Interacting with Public Policy } \\
\text { has explored the different ways that } \\
\text { public policies impact HCI and, } \\
\text { conversely, how HCI can and has } \\
\text { impacted public policies.” Public } \\
\text { policy is maybe not on the mind of } \\
\text { every HCI researcher or practitioner, } \\
\text { but Jonathan has done a wonderful job } \\
\text { over the years in spreading knowledge } \\
\text { about issues and challenges that have } \\
\text { policy or ethical implications. He } \\
\text { has specifically been instrumental in } \\
\text { broadening our global perspective. } \\
\text { We thank him for his extraordinary } \\
\text { time with Interactions! }\end{array}$ \\
\hline
\end{tabular}

We also want to welcome Loren Terveen, who is the new president of ACM SIGCHI. Loren will continue the Community Square column in the magazine. We look forward to getting reports about SIGCHI, its plans, and its future.

As always, we are looking forward to your feedback on articles and welcome your contributions to the many departments within the magazine, including short opinion pieces in Confessions, new and novel prototypes in Demo Hour, targeted articles submitted to our forums, as well as feature articles and cover stories. Please contact us with your submissions.

Ron Wakkary and Erik Stolterman eic@interactions.acm.org

\section{Bødker revisits her famous keynote and reports on what has happened in the past 10 years.}

